\title{
Faktor-Faktor yang Meningkatkan Prognosis Fetal dan Maternal pada Kehamilan dengan Kanker Ovarium
}

\author{
Efriyan Imantika ${ }^{1}$, Shinta Prawitasari ${ }^{2}$, Diah Rumekti Hadiati ${ }^{3}$ \\ ${ }^{1,2,3}$ Departemen Obstetri dan Ginekologi FK-KMK UGM \\ Korespondensi: rayan.rianto@gmail.com
}

Submisi:22 November 2019; Revisi:23 November 2019; Penerimaan:4 Desember 2019

\begin{abstract}
Background: Pregnancy complicated by ovarian cancer presents relation between controlled growth in pregnancy and uncontrolled growth in cancer. The management of pregnancy illustrate conflict between optimal maternal therapy and fetal life for best prognosis at all. The incidence was low but it occured in reproductive age women and most found in the first pregnancy. It is important to analyze factors that improve the prognosis of pregnancy and appropiate management to prevent fetal and maternal morbidity and mortality.

Objective: To analyze factor on pregnancy complicated by ovarian cancer that improve fetal and maternal prognosis

Method: This is descriptive analytic study with cohort retrospective design using medical records of pregnancy patient complicated by ovarian cancer that underwent treatment at Sardjito Hospital Yogyakarta on 2010, January till 2017, December. All statistical analysis were done by statistic software for computer.

Results adn Discussion: There were 18 research subjek had been undergone treatment at Sardjito Hospital for 8 years. Factors on pregnancy related to prognosis of pregnancy complicated by ovarian cancer were late gestational age at the cancer diagnosis and epithelial histopathology type. That factors have better prognosis than early gestational age and non-epithelial histopathology clinically $(p=0.18 ; C l 95 \% 0.4-104.2 ; O R \quad 6,5)$ and $(p=0.29$; $\mathrm{Cl} 95 \%$ 0.36-30.12; OR 3.28). Timing of surgery intervention improve prognosis of pregnancy statistically and clinically significant ( $p=0.02 ; O R=4.2)$.

Conclusion: Factors on pregnancy complicated by ovarian cancer that is late gestational age at the cancer diagnosis, epithelial histopathology type and timing of surgery intervention type II-III improved fetal and maternal prognosis. Best management of pregnancy lead to better prognosis.
\end{abstract}

Keywords: prognosis of pregnancy; ovarian cancer.

\begin{abstract}
ABSTRAK
Latar Belakang: Kehamilan dengan kanker merupakan hubungan 2 hal yang berlawanan antara pertumbuhan yang terkontrol pada kehamilan dan pertumbuhan yang tidak terkontrol pada kanker. Manajemen kehamilan dengan kanker menggambarkan konflik antara terapi optimal untuk ibu dan kehidupan janin. Kehamilan dengan kanker ovarium terjadi pada wanita usia reproduktif sehingga meskipun angka kejadiannya rendah, upaya pencegahan terjadinya mortalitas dan morbiditas pada ibu sangat penting karena mempengaruhi prognosis kehamilan. Hal ini dapat dilakukan dengan tepat jika pengenalan terhadap faktor-faktor yang berhubungan dengan prognosis kehamilan dengan kanker ovarium dilakukan dengan baik.

Tujuan: Membandingkan prognosis kehamilan yang terdiagnosis dengan keganasan ovarium pada usia kehamilan awal dibandingkn usia kehamilan lanjut dan menghitung besarnya kemungkinan untuk memiliki prognosis kehamilan yang baik

Metode: Penelitian ini adalah deskriptif analitik dengan rancangan penelitian cohort retrospektif menggunakan rekam medis ibu hamil dengan kanker ovarium yang menjalani pengobatan di poliklinik MFM, IMP dan atau bangsal Bugenvil 1 RSUP dr. Sardjito Yogyakarta mulai Januari 2010- Desember 2017. Analisis data menggunakan software statistik untuk komputer.

Hasil dan Pembahasan: Terdapat 18 subyek penelitian yang menjalani pengobatan di RSUP dr. Sardjito selama 8 tahun. Faktor-faktor yang berperan terhadap prognosis kehamilan dengan kanker ovarium yaitu usia kehamilan lanjut saat terdiagnosis dan jenis histopatologi epithelial. Kedua faktor tersebut memiliki prognosis yang lebih baik dibandingkan usia kehamilan dini dan jenis histopatologi non-epithelial secara klinis ( $p=0.18$; $\mathrm{Cl} 95 \%$ 0.4104.2; OR 6,5) dan ( $p=0.29$; Cl 95\% 0.36-30.12; OR 3.28). Waktu intervensi pembedahan meningkatkan prognosis kehamilan secara signifikan baik statistic maupun klinis ( $\mathrm{p}=0.02 ; \mathrm{OR}=4.2)$.

Kesimpulan: Faktor-faktor pada kehamilan dengan kanker ovarium yaitu usia kehamilan lanjut pada saat terdiagnosis, jenis histopathologi epithelial dan waktu intervensi pembedahan (tipe II-III) meningkatkan prognosis fetal dan maternal. Penanganan terbaik terhadap kehamilan memberikan prognosis yang lebih baik.
\end{abstract}

Kata kunci: prognosis kehamilan; kanker ovarium 


\section{PENDAHULUAN}

Angka kejadian kehamilan pada wanita yang menderita keganasan dibidang ginekologis semakin meningkat. Keganasan ginekologis yang paling banyak terdiagnosis dalam kehamilan yaitu keganasan serviks diikuti dengan keganasan ovarium. Berdasarkan Riskerdas tahun 2007, dinyatakan bahwa kanker serviks uteri dan ovarium merupakan jenis kanker yang paling banyak dijumpai di Indonesia. Kanker ovarium menempati kedudukan kedua setelah kanker serviks untuk keganasan ginekologis namun angka kejadiannya pada kehamilan tidak ditemukan data yang jelas. Sebagai jenis kanker yang mendominasi, kanker serviks dan ovarium paling banyak ditemukan pada perempuan usia dewasa, pernah kawin dan tingkat pendidikan rendah. ${ }^{1}$

Informasi mengenai wanita hamil dengan keganasan sering tidak terdokumentasi dengan baik, padahal dinyatakan bahwa ditemukan sitologi abnormal pada $5 \%$ dari seluruh kehamilan. ${ }^{2}$ Jumlah wanita hamil yang datang atau dirujuk dengan keluhan massa di abdomen selama kehamilan ke RSUP dr. Sardjito Yogyakarta cukup banyak. Selama kurun waktu Januari 2010-Desember 2017 terdapat 56 kasus kehamilan dengan massa di abdomen dan sepertiga nya terdiagnosis dengan keganasan ovarium baik potensi keganasan rendah maupun potensi keganasan tinggi.

Kehamilan dengan keganasan merupakan hubungan 2 hal yang berlawanan antara pertumbuhan yang terkontrol pada kehamilan dan pertumbuhan yang tidak terkontrol pada keganasan. Terapi pembedahan kehamilan dengan keganasan menggambarkan konflik antara upaya optimal untuk ibu dan kehidupan janin. Dilema akan terjadi jika pasien datang pada usia kehamilan antara 20-32 minggu. Penundaan pengobatan sampai dengan usia kehamilan 32 minggu untuk pematangan paru janin diikuti dengan sesarean radikal histerektomi direkomendasikan pada seluruh keganasan. Namun risiko terjadinya perdarahan pada manajemen pembedahan ini cukup besar sehingga harus dilakukan dengan penuh pertimbangan. ${ }^{3}$

Beberapa penelitian epidemiologik menunjukkan peran protektif progesteron dalam mempertahankan kehamilan dengan keganasan ovarium. Penelitian eksperimental lainnya melaporkan bahwa kadar progesteron yang tinggi pada kehamilan menginduksi apoptosis sel-sel kanker pada keganasan ovarium melalui jalur intrinsik dan ekstrinsik. Progesteron menunjukkan efek anti kanker yang nyata melalui aksi genomik dan non genomik. Hal ini sesuai dengan faktor risiko terjadinya kanker ovarium itu sendiri yaitu infertilitas. Efek kehamilan terhadap keganasan ovarium lainnya yaitu mengurangi paparan terhadap ovulasi yang merupakan faktor predsposisi terjadinya keganasan ovarium epitelial dan tingginya kadar progesteron menghambat tumorigenesis ovarium dengan cara mencegah gangguan integritas epitelial ovarium. ${ }^{4}$

Penelitian tentang efek keganasan ovarium terhadap kehamilan jarang ditemukan, namun hasil histopatologis dan stadium dinyatakan merupakan faktor yang paling bertanggung jawab terhadap luaran kehamilan dengan keganasan ovarium. Kesulitan yang ditemukan secara tidak langsung yaitu penegakan diagnosis keganasan ovarium dalam kehamilan dikarenakan sebagian besar bersifat asimptomatik dan biasanya datang pada stadium lanjut. Penentuan keputusan intervensi medis dilakukan dengan memikirkan prognosis ibu dan janinnya. ${ }^{5,6}$

Kehamilan yang terjadi pada wanita yang menderita keganasan ovarium memiliki risiko terhadap janin berupa terjadinya keguguran, kelahiran prematur, pertumbuhan janin terhambat sampai dengan kelainan kongenital. Janin dianggap viabel secara biomedis dan sesuai dengan kapasitas teknologi pada usia kehamilan sekitar 24 minggu. ${ }^{7}$ Setelah masa tersebut, kemoterapi ataupun tindakan pembedahan dapat dilakukan dengan risiko keguguran atau kelahiran prematur. Risiko malformasi jika kemoterapi diberikan pada trimester pertama berkisar 7,5-17\% dan risiko teratogenik meningkat dengan pemberian kombinasi. Abortus spontan terjadi pada bulan pertama kehamilan yang terpapar agen sitotoksik sedangkan defek terjadi pada minggu 5-12 kehamilan yaitu pada masa organogenesis. ${ }^{3,8}$

Di Indonesia data mengenai kehamilan dengan keganasan ovarium belum terdokumentasi dengan baik, khususnya di RSUP dr. Sardjito Yogyakarta. Kehamilan dengan keganasan ovarium terjadi 
pada wanita usia reproduktif dan sebagian besar terdiagnosis pada kehamilan pertamanya, sehingga meskipun angka kejadiannya rendah, upaya pencegahan terjadinya mortalitas dan morbiditas pada ibu sangat penting karena mempengaruhi prognosis kehamilan. Karakteristik keganasan ovarium yang sering menimbulkan keluhan setelah terdiagnosis pada stadium akhir (silent killer) membutuhkan perhatian khusus terutama pada wanita hamil. Hal ini dapat dilakukan jika faktor dalam kehamilan yang berhubungan dengan prognosis kehamilan dengan keganasan ovarium dilakukan dengan tepat. Kehamilan dengan keganasan ovarium terdiri dari 3 komponen utama yaitu kehamilan, faktor maternal dan karakteristik keganasan ovarium. Identifikasi ketiga hal tersebut sedini mungkin untuk mempertimbangkan bentuk dan waktu intervensi yang akan dilakukan, diharapkan dapat memperbaiki prognosis kehamilan. Penilaian prognosis kehamilan dengan keganasan ovarium meliputi kehamilan itu sendiri yang berhubungan langsung dengan luaran fetal dan luran maternal.

\section{METODE}

Jenis penelitian ini adalah deskriptif analitik dengan rancangan penelitian cohort retrospektif menggunakan rekam medis ibu hamil dengan keganasan ovarium yang menjalani pengobatan di poliklinik MFM, IMP dan atau di Bugenvil 1 RSUP dr. Sardjito Yogyakarta mulai Januari 2010-Desember 2017.

Data penelitian ini menggunakan data sekunder yang diperoleh dari rekam medis pasien hamil dengan keganasan ovarium yang masuk melalui dan atau menjalani pengobatan di poliklinik MFM, IMP dan atau di Bugenvil 1 RSUP dr. Sardjito Yogyakarta mulai Januari 2010-Desember 2017.

Analisis univariat dilakukan dengan menggunakan program software komputer untuk statistik deskriptif dengan menampilkan karakteristik subjek penelitian, frekuensi dan persentase masingmasing subjek berdasarkan variabel penelitian. Analisis bivariat menggunakan Fisher Exact Test alternatif chi dengan derajat kemaknaan $\mathrm{p}<0.05$ dan confident interval 95\%. Penelitian ini dilakukan dengan mendapat persetujuan dan surat kelaikan etik penelitian dari Komite Etika Penelitian Biomedis Fakultas Kedokteran Universitas Gadjah Mada dengan nomor: KE/FK/0441/EC/2017.

\section{HASIL DAN PEMBAHASAN}

Karakteristik pasien penelitian meliputi rerata usia pasien, paritas, usia kehamilan saat terdiagnosis, keluhan utama pasien, usia kehamilan saat dilakukan intervensi dan lamanya waktu konservatif kehamilan setelah dilakukan intervensi. Dari tabel 1 terlihat bahwa rerata usia 18 pasien penelitian termasuk dalam usia reproduksi yaitu $27,8 \pm 7,48$ dengan $2 / 3$ nya adalah primigravida dan hanya $1 / 3$ pasien yang merupakan multigravida. Sebagian besar pasien terdiagnosis terdapat massa adneksa pada trimester pertama dan kedua dengan rerata usia kehamilan saat terdiagnosis yaitu 19,8 $\pm 6,68$ minggu sedangkan rerata usia kehamilan saat dilakukan intervensi yaitu $30,39 \pm 8,2$ minggu. Rerata durasi waktu konservatif kehamilan setelah dilakukan intervensi yaitu 47,4 \pm 66,4 hari atau sekitar 6-7 minggu. 
Tabel 1. Karakteristik pasien hamil dengan keganasan ovarium

\begin{tabular}{lc}
\hline \multicolumn{1}{c}{ Karakteristik } & Rerata \pm Simpangan Baku/n (\%) \\
\hline Usia & $27,8 \pm 7,48$ \\
Usia Kehamilan Saat Terdiagnosis (minggu) & $19,8 \pm 6,68$ \\
Usia Kehamilan Saat Intervensi (minggu) & $30,39 \pm 8,2$ \\
Lama waktu konservatif (hari) & $47,4 \pm 66,4$ \\
Paritas & \\
Primigravida & $12(67 \%)$ \\
Sekundi/Multigravida & $6(33 \%)$ \\
Rerata Lama hidup & $13,43 \mathrm{bulan}$ \\
Meninggal & $9(50 \%)$ \\
Hidup & $9(50 \%)$ \\
Luaran Janin & \\
Abortus & $5(27,8 \%)$ \\
Preterm & $6(33,3 \%)$ \\
Aterm & $7(38,9 \%)$ \\
\hline
\end{tabular}

Karakteristik tumor meliputi subtipe histologi, stadium awal saat terdiagnosis/ saat dilakukan intervensi, grading tumor berdasarkan FIGO dan pemilihan metode penatalaksanaan yang dilakukan terhadap pasien termasuk pemberian kemoterapi. Dari tabel 2 menunjukkan bahwa jenis histopatologi terbanyak yang diderita pasien adalah keganasan epithelial invasive tipe serous sebanyak 33\% dan mucous $16,7 \%$ diikuti oleh jenis germ cell tumor sebanyak $27 \%$ dan borderline malignancy (low potential malignancy) sebanyak $22 \%$.

Tabel 2. Karakteristik histopatologi keganasan ovarium pada kehamilan

\begin{tabular}{lc}
\hline \multicolumn{1}{c}{ Tipe Histopatologi } & $\begin{array}{c}\text { Persentase Jumlah Pasien } \\
\mathbf{N}(\%)\end{array}$ \\
\hline Borderline Malignancy & \\
$\quad$ Mucinous & $3(16,7)$ \\
$\quad$ Serous & $1(5,6)$ \\
Keganasan epithelial & \\
invasive & $3(16,7)$ \\
$\quad$ Musinous & $6(33,3)$ \\
$\quad$ Serous & \\
Germ cell tumors & \\
$\quad$ Disgerminoma & $2(11,1)$ \\
$\quad$ Teratoma immatur & $3(16,7)$ \\
\hline
\end{tabular}

Jenis germ cell tumor (GCT) yang sering ditemukan pada kehamilan yaitu teratoma immatur dan disgerminoma. Pada penelitian ini juga ditemukan jenis histopatologi borderline dengan perbandingan tipe musinous lebih banyak ditemukan daripada tipe serous namun sebaliknya pada keganasan jenis epithelial invasif lebih banyak ditemukan tipe serous daripada musinous. Variabel jenis histopatologi ini dibagi berdasarkan jenis sel keganasannya yaitu epithelial dan non epithelial. 
Tabel 3. Pola terapi pembedahan berdasarkan jenis histopatologi

\begin{tabular}{lcccc}
\hline \multicolumn{1}{c}{ Histopatologi } & Biopsi & Kistektomi & $\begin{array}{c}\text { Salphingo } \\
\text { oophorectomy }\end{array}$ & POA \\
\hline Borderline malignancy $(n=4)$ & 0 & $50 \%$ & $50 \%$ & 0 \\
Keganasan epitel invasif $(n=9)$ & $11,1 \%$ & $11,1 \%$ & $44,4 \%$ & $33,3 \%$ \\
Germ Cell Tumor $(n=5)$ & $40 \%$ & $20 \%$ & $40 \%$ & 0 \\
\hline
\end{tabular}

Tabel 3 menunjukkan pola terapi pembedahan berdasarkan jenis histopatologinya. Pembedahan radikal meliputi histerektomi radikal, omentektomi dan appendektomi post partum dikerjakan pada $33,3 \%$ pasien dengan keganasan epithelial invasif. Tindakan pembedahan dengan biopsi saja dikerjakan pada 2 pasien dengan keganasan sel germinal dan dilakukan pada Rumah Sakit daerah sedangkan 1 pasien dengan keganasan epitel yang datang sudah dalam stadium lanjut.

Tabel 4. Pola keluhan utama pasien hamil dengan massa abdomen

\begin{tabular}{llr}
\hline \multicolumn{1}{c}{ Pola Keluhan } & $\mathbf{n}$ & \multicolumn{1}{c}{$\%$} \\
\hline Teraba Massa Abdomen & 8 & 44.4 \\
Nyeri Abdomen & 1 & 5.6 \\
Gangguan Pencernaan & 3 & 16.6 \\
Tidak ada keluhan & 6 & 33.3 \\
\hline
\end{tabular}

Tabel 4 menunjukkan keluhan pasien yang hamil sebelum terdiagnosis dengan keganasan ovarium. Keluhan terbanyak yang dirasakan pasien yaitu teraba massa yang semakin membesar dengan cepat terutama pada usia kehamilan trimester awal. Sebagian besar pasien datang tanpa keluhan dan ditemukan adanya massa pada saat pemeriksaan kehamilan melalui ultrasonografi.

Pada tabel 5 menunjukkan hubungan antara usia kehamilan saat terdiagnosis dengan prognosis kehamilan dan variabel keganasan ovarium berupa jenis histopatologis, stadium klinis, grading sel keganasan berdasarkan FIGO, pemberian kemoterapi dan terapi pembedahan yang dilakukan terhadap kehamilan dan keganasan ovarium yang ditemukan. Dari keenam hubungan yang dianalisis tersebut, hanya satu variabel yang bermakna secara statistik dengan nilai $p<0,05$ yaitu hubungan antara terapi pembedahan yang dilakukan dengan prognosis kehamilan $(p=0,02)$. Hal tersebut dikarenakan hanya terdapat 1 pasien yang melahirkan bayi dengan berat badan $1200 \mathrm{~kg}$ pada usia kehamilan 30 minggu 1 hari secara perabdominal. Kehamilan ini disertai dengan kelainan berupa polihidramnion dan bayi yang dilahirkan meninggal setelah 24 jam dilahirkan.

Hubungan antara grading FIGO dengan prognosis kehamilan memiliki nilai $R R \quad 1,15$ menunjukkan bahwa kehamilan dengan keganasan ovarium dengan differensiasi baik memiliki prognosis kehamilan 1,15 kali lebih baik dibandingkan pada differensiasi sedang-buruk. Pemberian kemoterapi juga memiliki nilai RR 1,2 yang menunjukkan bahwa pemberian kemoterapi pada kehamilan dengan keganasan ovarium memiliki prognosis 1,2 kali lebih baik dibandingkan yang tidak diberikan kemoterapi. Hubungan terapi pembedahan yang dilakukan pada kehamilan dengan keganasan ovarium dengan prognosis kehamilan memiliki nilai $p=0,02$ dengan nilai $R R 1,08$, artinya pemilihan terapi pembedahan yang dilakukan yaitu tipe II-III meningkatkan prognosis kehamilan sebesar 4,2 kali lipat dibandingkan tipe I. 
Tabel 5. Hubungan usia kehamilan dengan prognosis kehamilan dan variabel keganasan ovarium

\begin{tabular}{|c|c|c|c|c|c|}
\hline \multirow{2}{*}{ Variabel } & \multicolumn{2}{|c|}{ Luaran Kehamilan } & \multirow{2}{*}{$\mathbf{p}$} & \multirow{2}{*}{$\mathbf{R R}$} & \multirow{2}{*}{ IK 95\% } \\
\hline & Baik & Jelek & & & \\
\hline \multicolumn{6}{|c|}{ Usia kehamilan saat terdiagnosis } \\
\hline Lanjut & 11 & 3 & $0,08^{a}$ & 3,1 & $(0,56-17,5)$ \\
\hline Awal & 1 & 3 & & & \\
\hline \multicolumn{6}{|l|}{ Tipe histopatologis } \\
\hline Epitelial & 9 & 2 & $0,1^{\mathrm{a}}$ & 1,9 & $(0,77-4,69)$ \\
\hline Non-epitelial & 3 & 4 & & & \\
\hline \multicolumn{6}{|l|}{ Stadium Klinis } \\
\hline Lanjut & 4 & 1 & $0,4^{\mathrm{a}}$ & 1,3 & $(0,7-2,4)$ \\
\hline Awal & 8 & 5 & & & \\
\hline \multicolumn{6}{|l|}{ Grading FIGO } \\
\hline Grd 1 & 9 & 4 & $0,5^{\mathrm{a}}$ & 1,15 & $(0,38-7,9)$ \\
\hline Grd 2-3 & 3 & 2 & & & \\
\hline \multicolumn{6}{|l|}{ Kemoterapi } \\
\hline Ya & 8 & 3 & $0,4^{\mathrm{a}}$ & 1,2 & $(0,6-2,65)$ \\
\hline Tidak & 4 & 3 & & & \\
\hline \multicolumn{6}{|l|}{ Terapi pembedahan } \\
\hline Tipe II-III & 11 & 2 & $0,02^{a^{*}}$ & 4,2 & $(0,7-24,8)$ \\
\hline Tipe I & 1 & 4 & & & \\
\hline
\end{tabular}

aji fisher, $* p<0,05$

Kodama et al., 2014 membedakan keempat pola penanganan pasien tersebut yaitu tipe I pasien terdiagnosis keganasan dan dilakukan intervensi antepartum diikuti dengan terminasi kehamilan, tipe II pasien terdiagnosis dan dilakukan intervensi antepartum namun dilakukan konservatif terhadap kehamilannya, tipe III pasien terdiagnosis antepartum namun intervensi dilakukan intrapartum atau postpartum, tipe IV pasien terdiagnosis intrapartum dan dilakukan intervensi intra/ post partum. Pada penelitian ini, terapi pembedahan yang dilakukan pada pasien dengan keganasan ovarium hanya sesuai dengan tipe I, II dan III. ${ }^{9}$ 
Tabel 6. Hubungan usia kehamilan dan variabel keganasan ovarium dengan Berat Badan Lahir

\begin{tabular}{|c|c|c|c|c|c|}
\hline \multirow{2}{*}{ Variabel } & \multicolumn{2}{|c|}{ Berat Badan Lahir } & \multirow{2}{*}{$\mathbf{p}$} & \multirow{2}{*}{$\mathbf{R R}$} & \multirow{2}{*}{ IK 95\% } \\
\hline & Tidak IUGR & IUGR & & & \\
\hline \multicolumn{6}{|c|}{ Usia kehamilan saat terdiagnosis } \\
\hline Lanjut & 13 & 1 & $0,78^{a}$ & 0,9 & $(0,8-1,07)$ \\
\hline Awal & 4 & 0 & & & \\
\hline \multicolumn{6}{|l|}{ Tipe histopatologis } \\
\hline Epitelial & 10 & 1 & $0,6^{a}$ & 0,9 & $(0,7-1,09)$ \\
\hline Non-epitelial & 7 & 0 & & & \\
\hline \multicolumn{6}{|l|}{ Stadium Klinis } \\
\hline Lanjut & 4 & 0 & $0,28^{a}$ & 0,8 & $(0,9-1,27)$ \\
\hline Awal & 13 & 1 & & & \\
\hline \multicolumn{6}{|l|}{ Grading FIGO } \\
\hline Grd 1 & 12 & 1 & $0,7^{\mathrm{a}}$ & 1,08 & $(0,9-1,27)$ \\
\hline Grd 2-3 & 5 & 0 & & & \\
\hline \multicolumn{6}{|l|}{ Kemoterapi } \\
\hline Ya & 10 & 1 & $0,6^{\mathrm{a}}$ & 0,9 & $(0,75-1,09)$ \\
\hline Tidak & 7 & 0 & & & \\
\hline \multicolumn{6}{|l|}{ Terapi pembedahan } \\
\hline Tipe II-III & 12 & 1 & $0,7^{\mathrm{a}}$ & 1,08 & $(0,8-1,07)$ \\
\hline Tipe I & 5 & 0 & & & \\
\hline
\end{tabular}

a Uji fisher

Hubungan antara usia kehamilan saat terdiagnosis keganasan ovarium dengan berat badan lahir ditunjukkan pada tabel 6 , Tidak ada variabel yang berhubungan signifikan secara statistik. Hal ini disebabkan sebagian besar berat badan lahir bayi pada kehamilan dengan keganasan ovarium pada penelitian ini memiliki berat badan lahir yang sesuai dengan usia kehamilannya. Beberapa variabel bermakna secara klinis yaitu grading FIGO dan pemberian terapi pembedahan terapi dengan nilai $\mathrm{RR}=1,08$, Hal ini menunjukkan bahwa kehamilan dengan keganasan ovarium pada differensiasi baik memiliki prognosis lebih baik 1,08 dibandingkan differensiasi sedang-buruk. Pemilihan terapi pembedahan terapi tipe II-III (terapi pembedahan konservatif) juga memiliki prognosis kehamilan 1,08 kali lebih baik dibandingkan tipe I.

Dua variabel yang bermakna secara klinis yaitu grading FIGO dan pemberian terapi pembedahan terapi berhubungan dengan Berat Badan Lahir bayi dengan nilai $R R=1,08$. Hal ini menunjukkan bahwa kehamilan dengan keganasan ovarium pada differensiasi baik memiliki Berat Badan Lahir lebih baik 1,08 dibandingkan differensiasi sedang-buruk. Pemilihan terapi pembedahan terapi tipe II-III (manajemen konservatif) juga memiliki Berat Badan Lahir 1,08 kali lebih baik dibandingkan tipe I.

Analisis multivariat antara variabel terikat, variabel bebas dan variabel luar yang memiliki nilai $p<0,25$ ditunjukkan pada tabel 7 , Variabel yang dapat dilakukan analisis multivariat yaitu terapi pembedahan yang dilakukan kepada pasien $(p=0,02)$, usia kehamilan saat terdiagnosis $(p=0,08)$ dan jenis histopatologis keganasan ovarium $(p=0,11)$. Nilai $p$ pada ketiga variabel lebih besar dari 0,05 namun nilai OR pada masing-masing variabel yaitu $O R=1,5$ untuk terapi pembedahan pasien, $\mathrm{OR}=6,5$ untuk variabel usia kehamilan saat terdiagnosis dan $\mathrm{OR}=3,28$ untuk variabel jenis histopatologis keganasan ovarium. Artinya secara klinis, ketiga variabel tersebut menentukan prognosis kehamilan yang baik pada kehamilan dengan keganasan ovarium. 
Tabel 7. Analisis multivariat kehamilan dengan keganasan ovarium dengan prognosis kehamilan dan variabel luar

\begin{tabular}{lcccc}
\hline \multicolumn{1}{c}{ Variabel } & Koefisien & Nilai $\mathbf{p}$ & OR & IK 95\% \\
\hline Terapi pembedahan & 0,41 & 0,76 & 1,5 & $(0,1-22,88)$ \\
Usia kehamilan saat terdiagnosis & 1,87 & 0,18 & 6,5 & $(0,4-104,2)$ \\
Tipe histopatologis & 1,19 & 0,29 & 3,28 & $(0,36-30,12)$ \\
Konstanta & $-1,69$ & 0,15 & 0,18 & \\
\hline
\end{tabular}

Persamaan regresi logistik yang diperoleh berdasarkan tabel diatas yaitu:

$y=-1.69+0.41$ (Terapi pembedahan) +1.87

(Usia kehamilan) + 1.19 (tipe histopatologis)

Probabilitas individu yang hamil dengan keganasan ovarium untuk memiliki prognosis kehamilan yang baik yaitu:

$$
p=\frac{1}{1+\exp [-(y)]}
$$

Dari penelitian ini ditemukan jenis histopatologi terbanyak yaitu jenis keganasan ovarii invasif dengan subtype serous sebanyak $50 \%$ pasien, urutan kedua berasal dari malignant germ cell tumor (MGCT) sebanyak $27,8 \%$ pasien dengan subtype teratoma immature (16,7\%) dan dysgerminoma (11,1\%), selebihnya adalah low potensial malignancy (borderline tumour) sekitar 22\%. Kodama et al, 2014 mereview kehamilan dengan keganasan ovarium jenis malignant germ cell tumor (MGCT) dan menemukan kasus terbanyak yaitu dysgerminoma $(38,2 \%)$ dan yolk sac tumor $(30,4 \%)$.

Sebagian besar kehamilan dengan keganasan ovarium pada penelitian ini terdiagnosis pada trimester kedua dengan keluhan utama perut yang membesar tidak sesuai dengan usia kehamilannya. Stadium klinis saat terdiagnosis sebagian besar dengan stadium I sebanyak $67 \%$ dan selebihnya ditemukan pada stadium lanjut. Setelah dilakukan tindakan pembedahan, hanya 1 kasus yang mengalami peningkatan stadium dari stadium awal menjadi stadium lanjut. Hal ini sesuai dengan penelitian Kodama et al, 2014 dan Kwon et al, 2010 yang menyatakan bahwa kehamilan dengan keganasan ovarium paling banyak terdiagnosis pada stadium I $(76,4 \%)$ dengan rerata ukuran tumor
17,9 cm. Menurut Blake et al, 2015, kehamilan dengan keganasan ovarium jenis epithelial invasif paling banyak ditemukan pada stadium lanjut. Hal ini sesuai dengan penelitian ini, kehamilan dengan keganasan epithelial invasif sebagian datang dengan stadium lanjut (45\%). . $^{5,910}$

Blake et al, 2013 menyatakan bahwa sebagian besar pasien dengan EOC terdiagnosis pada stadium I $(63,8 \%)$ sedangkan sebagian besar EOC pada wanita tidak hamil terdiagnosis pada stadium lanjut (67\%). Sedangkan untuk keganasan ovarium jenis non epithelial, stadium I paling banyak ditemukan $(63,8 \%)$ diikuti stadium III (24,8\%). Sebagian besar kasus diberikan kemoterapi $(55,2 \%)$ sehingga 21 janin terpapar obat anti kanker in-utero. Dengan demikian, kehamilan tidak mengubah survival rate pasien dengan EOC dan adanya kehamilan tidak mempengaruhi keputusan pembedahan awal atau pemberian kemoterapi dan keterlambatan penanganan karena kehamilan berhubungan dengan efek negatif luaran pasien. Pemberian kemoterapi selama kehamilan merupakan strategi yang paling mungkin untuk meningkatkan luaran maternal dan fetal, namun tetap berisiko terhadap janin terutama jika pemberiannya dilakukan pada saat organogenesis yang berhubungan dengan peningkatan kejadian abortus dan malformasi janin. ${ }^{10}$

Dari berbagai jenis keganasan ovarium, jenis sel epitel merupakan varian paling sering dan menyumbangkan morbiditas dan mortalitas terbanyak. Tumor epitel serous memiliki insidensi tertinggi sekitar $70 \%$ jenis tumor epitel origin dan selebihnya subtipe lain yang paling sering mucinous, endometrioid dan clear cell. Keganasan ovarium menjadi jenis kanker ke- 5 yang terdiagnosis selama kehamilan. Meskipun prevalensi EOC rendah pada wanita usia reproduksi, jenis sel epitel memberikan sekitar 25-50\% keganasan ovarium yang terdiagnosis dalam kehamilan. ${ }^{10}$ 
Keseluruhan kelahiran hidup pada penelitian ini sebanyak $61,1 \%$ dengan usia kelahiran aterm $33,3 \%$ sedangkan $27,8 \%$ berakhir dengan keguguran yang terjadi secara spontan setelah dilakukan intervensi. Terminasi kehamilan pada usia kehamilan kurang dari 22 minggu atau berat kurang dari 500 gram dalam penelitian ini keseluruhan terjadi secara spontan. Berbeda dengan manejemen tipe I yang pada alur penanganan yang ada, dimana terminasi dilakukan secara elektif. ${ }^{9}$

Sebanyak $66,7 \%$ pasien pada penelitian ini merupakan primigravida dan 33,3\% nya merupakan sekundi dan multigravida. Keganasan ovarium dalam kehamilan paling sering ditemukan pada primigravida dibandingkan dengan sekundimultigravida, namun patofisiologi terjadinya fenomena tersebut belum ditemukan, diduga berhubungan dengan adanya perubahan hormonal akibat kehamilan pertumbuhan massa tumor terjadi secara progresif sehingga menimbulkan manifestasi klinis. $^{5}$

Rerata berat lahir pada penelitian ini yaitu 1723 gram dengan IUGR ditemukan hanya 1 kasus. Terjadinya IUGR tersebut bukan dikarenakan paparan agen kemoterapi namun lebih disebabkan oleh malnutrisi karena ibu mengalami cachexia akibat keganasan ovarium yang dideritanya. Calsteren et al, 2010 menyatakan bahwa adanya pertumbuhan dan pembesaran tumor yang cepat dari dari jenis germ cell tumor menurunkan perfusi plasenta yang mungkin menerangkan mekanisme biologi fenomena tersebut. Sebagian besar kehamilan yang diterapi pembedahan ekspektatif memberikan luaran neonatal yang baik. Komplikasi selama kehamilan lebih banyak ditemukan pada jenis histopatologi lain. ${ }^{11}$

Pada penelitian ini tidak ditemukan hubungan antara variabel keganasan ovarium terhadap terjadinya IUGR dan kelainan kongenital. Sejalan dengan penelitian Kodama et al, 2014 yang menemukan rerata berat lahir dari 102 kasus kehamilan dengan keganasan ovarium jenis germ cell tumor, rerata berat lahir bayi yaitu 2553 gram dengan IUGR pada $22,8 \%$ kasus. Tidak ditemukan hubungan signifikan antara paparan kemoterapi in utero dengan terjadinya IUGR dan malformasi kongenital. ${ }^{9} \mathrm{Hal}$ ini sesuai dengan penelitian
Blake et al, 2013 yang menemukan tidak terdapat hubungan terjadinya IUGR pada janin yang terpapar oleh kemoterapi, namun menurut literatur risiko terjadinya IUGR yaitu sebesar 7-24\% pada janin yang terpapar kemoterapi. Namun hal ini sebanding dengan peningkatan luaran fetal dengan dan maternal dengan pemberian kemoterapi. ${ }^{10,12}$

Rerata usia kehamilan saat persalinan pada penelitian ini yaitu 30,4 minggu yang meliputi usia kehamilan aterm $38 \%$, preterm $33,3 \%$ dan abortus $27,8 \%$. Jenis persalinan meliputi persalinan spontan pervaginal $55,6 \%$, perabdominal $27,8 \%$ dan abortus sebanyak 16,7\%. Menurut Calsteren et al, 2010 berdasarkan evidence morbiditas dan mortalitas neonatus terjadi paling banyak pada usia kehamilan late dan early preterm birth dibandingkan aterm dan paparan kemoterapi in utero tidak berisiko jika diberikan sekali dan penanganan tanpa diikuti kelahiran akan meningkatkan luaran ibu dan janin. Berdasarkan penelitian Kodama et al, 2014, pada kehamilan dengan keganasan ovarium jenis persalinan perabdominal aterm sebanyak $65,8 \%$ kasus, IUFD (3,9\%), kehamilan ektopik $(2,9 \%)$ dan abortus spontan (2,9\%). ${ }^{9,11}$

Pada penelitian ini, rerata waktu terapi pembedahan konservatif pada kehamilan dengan keganasan ovarium setelah intervensi untuk kelompok II dan III yaitu 7-10 minggu (47,4 \pm 66,4 hari) $98,3 \%$ dengan kelahiran hidup. Lama waktu konservatif ini dihitung dari usia kehamilan saat terdiagnosis sampai dengan usia kelahiran yang dapat berakhir dengan abortus atau persalinan vaginal preterm dan aterm. Pada persalinan perabdominal dilakukan secara elektif atau dengan indikasi obstetrik. Lama waktu konservatif ini berhubungan dengan pemilihan terapi pembedahan yang dilakukan dan berpengaruh secara tidak langsung terhadap prognosis kehamilan. Pada penelitian Blake et al, 2013, kehamilan diterapi pembedahan ekspektatif pada 59 kasus $(56,2 \%)$ dengan durasi 19 minggu. Proporsi kehamilan yang menjalani terapi pembedahan ekspektatif pada saat terdiagnosis trimester I, II dan III yaitu $72,1 \%, 70,8 \%$ dan $35,7 \%(p<0,01)$.

Tidak didapatkan hubungan antara kehamilan dengan keganasan ovarium dan pemberian kemoterapi dengan prognosis kehamilan dan ada 
tidaknya kelainan kongenital pada penelitian ini. Pada penelitian lain, didapatkan kelainan kongenital ventrikulomegali pada usia kehamilan 27 minggu setelah pemberian BEP pada usia kehamilan 25 minggu, 3 neonatus meninggal karena prematuritas dan 1 kasus menderita Potter syndrome. Efek BEP pada janin yang sedang berkembang meliputi neutropenia dan gangguan pendengaran dan pansitopenia transient setelah pemakain etoposide pada trimester ketiga. Tidak didapatkan risiko tetap pemakaian kemoterapi, kasus ventrikulomegali ditemukan setelah 2 minggu pemberian 1 siklus BEP. ${ }^{9}$

Pada penelitian ini, didapatkan bahwa terapi pembedahan yang dilakukan pada kehamilan dengan keganasan ovarium menentukan prognosis kehamilan, terapi pembedahan tipe II memiliki prognosis paling baik dibandingkan terapi pembedahan III. Penelitian Kodama et al, 2014 membagi terapi pembedahan menjadi 4 kelompok pada 102 kasus meliputi kelompok I pembedahan tumor dan terminasi kehamilan pada 21,6\% kasus, kelompok II terapi pembedahan ekspektatif kehamilan dengan pembedahan tumor pada $57,8 \%$, kelompok III pembedahan tumor setelah kelahiran pada $12,7 \%$ dan kelompok IV sebanyak $20,6 \%$ pembedahan tumor dilakukan intrapartum. Angka harapan hidup 5 tahun tertinggi didapatkan pada kelompok II, diikuti kelompok IV, kelompok III dan kelompok I $(p=0,028)$. Terapi pembedahan yang terbanyak dilakukan sesuai kelompok II $(45,1 \%)$ diikuti kelompok I (21,6\%), kelompok IV (20,6\%) dan kelompok III (12,7\%). Kelompok II dihubungkan dengan survival rate tertinggi dibandingkan kelompok III dan IV untuk luaran kehamilan yang viabel. Terapi pembedahan ekspektatif untuk MGCT menunjukkan luaran yang lebih baik untuk ibu dan janin meskipun $15,2 \%$ kehamilan menjalani pembedahan dengan preservasi janin menimbulkan rekurensi selama kehamilan. ${ }^{9,13}$

Terapi yang diberikan pada kehamilan dengan keganasan ovarium berupa tindakan bedah (laparotomy biopsi, kistektomi dengan atau tanpa diikuti histerektomi post partum) dan pemberian kemoterapiterapi jika hasil histopatologi ditemukan keganasan. Pada penelitian ini $77,8 \%$ pasien menjalani laparotomi kistektomi pada trimester
II kehamilan, 22,2\% pasien menjalani laparotomi biopsi dan $11,1 \%$ pasien yang telah menjalani kistektomi dilakukan debulking massa tumor post partum. Menurut Amant et al, 2009, penundaan pengobatan sampai dengan usia kehamilan 32 minggu untuk pematangan paru janin diikuti dengan sesarean radikal histerektomi direkomendasikan pada seluruh keganasan, sedangkan berdasarkan FIGO 2014, keganasan ovarium yang terdiagnosis sebagai stadium IA direkomendasikan pemeliharaan kesuburan dan mempertahankan kehamilan. Restaging setelah persalinan dianjurkan untuk eksplorasi menyeluruh dari massa ovarium. Tumor non epitelial berupa massa bulky yang terdiagnosis lebih dari $90 \%$ pada std IA FIGO diterapi juga dengan reseksi dan surgical staging. ${ }^{3,14}$

\section{KESIMPULAN DAN SARAN}

Faktor usia kehamilan lanjut pada saat terdiagnosis kanker ovarium dan jenis histopatologi epitel merupakan faktor terpenting yang meningkatkan prognosis kehamilan. Waktu intervensi pembedahan tipe II dan III memiliki prognosis kehamilan yang lebih baik dibandingkan tipe I.

\section{DAFTAR PUSTAKA}

1. Laporan hasil riset kesehatan dasar (RISKERDAS) nasional 2017. Kehamilan dengan kanker ginekologi. Laporan penelitian, Badan Penelitian dan Pengembangan Kementrian Kesehatan Republik Indonesia.

2. Graves CR, Parker L. 2008. Ovarian tumors complicating pregnancy. In: Te Linde's Operative Gynecology 10th ed. Philadelphia: Lippincott \& Wilkuns. Pp.842-50.

3. Amant F, Calsteren KV, Halaska MJ, Bejinen J, Lagae $L$, Hanssens $M$ et al. 2009. Gynecological cancer in pregnancy: Guidelines of an International consensus meeting. Int J of Gynecol Cancer: 19; 1-12.

4. Haan KH, Kim MK, Kim HS, Chung HH, Song YS. 2013. Protective effect of Progesterone during pregnancy against ovarian cancer. J Cancer prev 18:113-12.

5. Kwon YS, Mok JE, Lim KT, Lee IH, Kim TJ, Lee KH. 2010. Ovarian cancer during pregnancy: clinical and pregnancy outcome. J Korean Med Sci 25 (2): 230234.

6. Amneus $\mathrm{M}$, Hoischneider CH. 2012. Cancer in Pregnancy, In: Gynecoloy and Oncology clinical practice \& Surgical Atlas. United States: McGraw Hills. Pp.301-30. 
7. Chervenak FA, McCullough LB, Knapp RC, Caputo TA, Barber HRK. 2004. A clinically comprehensive ethical framework for offering and recommending cancer treatment before and during pregnancy. Cancer (100): 2.

8. Aziz S, Shafi MI. 2005. Malignancy in pregnancy. Curr Obstet Gynecol. Vol. 15:414-6.

9. Kodama M, Grubbs BH, Blake EA, Cahoon SS, Murakami R, Kimura T, Matsuo K. 2014. Fetomaternal outcomes of pregnancy complicated by ovarian malignant germ cell tumor: a systematic review of literature. Eur J Obstet \& Gynecol and Reprod Biol: 181 pp.145-156.

10. Blake EA, Carter CM, Kashani BN, Kodama M, Mabuchi S, Yoshino K, Matsuo K. 2014. Fetomaternal outcomes of pregnancy complicated by ovarian sex cord tumor: a systematic review literature. Eur $J$ of Obstet Gynecol and Reprod Biology. Vol 175; 1-7.
11. Calsteren KV, Heyns L, Smet FD, Eycken LV, Gziri MM, Gemert WV, Halaska M et al. 2010. Cancer during pregnancy: An analysis of 215 patients emphasizing the obstetrical and the neonatal outcomes. J of Clin Oncol: (28)4 pp.1-4.

12. Morice P, Uzan C, Gouy S, Verschargen, Meder $\mathrm{CH}$. 2012. Gynaecological cancers in pregnancy. The Lancet: 379.

13. Chan JK, Tewari KS, Waller S, Cheung MK, Shin JY, Osann K, Kapp DS. 2008. The influence of conservative surgical practices for malignant ovarian germ cell tumors. J surg oncol: 98(2) pp.111-116.

14. Mancari R, Tomasi N, Sarno MA, Azim HA, Franci D, Carinelli S, Biglia N, Colombo N, Peccatori FA. 2014. Treatment options for pregnant women with ovarian tumors. Int J Gyenecol Cancer (24): 967-972. 